\title{
Changing paradigm of Mercator to Accelya via Warburg Pincus - An information Technology Division of Emirate Group
}

\author{
Article history: \\ Received: 14 Jun 2019 \\ Sent for revision: 2 July 2019 \\ Received in revised form: 2 September 2019 \\ Accepted: 2 September 2019 \\ Available online: 15 October 2019
}

\begin{abstract}
Emirate Airline's parent company Emirate group created a separate division within group named as Mercator to meet the information technology (IT) needs of the group's companies. Mercator, IT division of Emirate group started serving other airlines and grown to have more than 120 airlines as its clients. This research paper presents the events connected to creation of Mercator and its merger/integration with Accelya via Warburg Pincus. The paper also presents critical analysis of Mercator growth model/strategy, business strategy, product innovation strategy, operation strategy, and overall strategy of existence based on the data with respect to its acquisitions, strategic partnerships, and decision of leadership based on commercial opportunities, product and service innovations, and selling of its both units, i.e., Mercator and Mercator Asia business. Research paper also analyzed changes in operations of Mercator under Emirate Group and under Warburg Pincus as Mercator and Accelya. Research paper included a brief introduction and historical perspective of Emirate airline \& Mercator, objective and research methodology, Mercator life, analysis of Mercator activities, followed by concluding remark.
\end{abstract}

Keywords: Emirate Airline, DNATA, Cloud Technology, Internet of Things, Customer Knowledge Warehouse, Mercator, Warburg Pincus, Accelya.

\footnotetext{
${ }_{1}^{1}$ Management Development Institute, Gurgaon, India. knpsingh@mdi.ac.in 


\section{Promena paradigme Mercator-a u Accelya preko Warburg Pincus - IT odeljenje u Emirate Group}

Apstrakt: Emirate group, matična kompanija Emirate Airline, otvorila je zasebno odeljenje unutar grupe pod nazivom Mercator kako bi zadovoljila potrebe za informacionim tehnologijama (IT) kompanija iz Grupe. Mercator, IT odeljenje Emirate Group, je započelo sa usluživanjem drugih aviokompanija $i$ ima više od 120 klijenata među aviokompanijama. Ovaj rad predstavlja događaje povezane sa stvaranjem Mercator-a $i$ njegovim spajanjem/integracijom sa Accelya preko Warburg Pincus-a. U radu je predstavljena i kritična analiza modela/strategije rasta Mercator-a, poslovne strategije, strategije inovacije proizvoda, strategije poslovanja i celokupne strategije postojanja zasnovane na podacima s obzirom na preuzimanje Mercator-a, strateško partnerstvo i odluke rukovodstva na osnovu komercijalnih mogućnosti, inovacija proizvoda i usluga i prodaje obe jedinice, tj. poslovanja Mercator-a i Mercator Azije. U radu su takođe analizirane promene u poslovanju Mercator-a u okviru Emirate Group i pod Warburg Pincus-om kao Mercator i Accelya. Rad sadrži kratak uvod i istorijski pregled aviokompanije Emirate \& i Mercator, cilj i metodologiju istraživanja, život Mercator-a, analizu njegovih aktivnosti, nakon čega slede završne napomene.

Ključne reči: Emirate Airline, DNATA, klaud tehnologija, internet stvari, skladište znanja kupaca, Mercator, Warburg Pincus, Accelya

\section{Introduction}

Emirate Airline is a subsidiary of the Emirates Group which is headquartered in Garhoud, Dubai, UAE. The Group comprises of DNATA, one of the largest air services provider globally to Emirates airline and other airlines. The group is known for innovating business processes with the innovation in the application of information technology in its day to day operations with an objective to bring efficiency in operations at reduced cost. Emirate Airline started its operations in 1985. Its first flight (EK600) operated between Dubai International Airport and Karachi Airport, Pakistan. In this way Emirates airline was born. Other two flights were for Mumbai (India) and Delhi (India). Emirates airline operated with just two aircraft initially. These were a Boeing 737-300 and an Airbus A300. Both these aircraft were leased from Pakistan International Airlines. In the same year a Boeing 727-200 was leased from the Dubai Air Wing. Initial funding was provided by Dubai government. It was US\$ 10 million. With this initial capital Emirate Airline became a self-financing organization/company. 
Singh N.P.: Changing paradigm of Mercator to Accelya via Warburg Pincus - An...

Emirate Airline first flight to Europe was in 1987. It was a non-stop flight to London Gatwick Airport. It was followed with flights from Dubai to Istanbul, Frankfurt, Bangkok, Manila and Singapore. Emirate Airline further initiated its expansion to Asia by 1989. In the first ten years of its operation, Emirates expanded its fleet to six Airbus A300 and eight Airbus A310 and established a network to cover 37 destinations in 30 countries. It was fastest growing airlines by the ' 90 s, with its revenue increasing US $\$ 100$ million year by year. More statistics with respect to turnover, net profit, passenger carried, number of aircraft, number of destinations, number of employees, passenger seat factor (\%), ASKM million, overall capacity, AKTM million, cargo carried (000 Tones), total assets, cash assets, and return on shareholders' funds are given in table 2(a) and 2 (b). Presently, it has a fleet of more than 268 aircraft. It flies to over 157 destinations in more than 83 countries. It is further expanding. More than 1,500 Emirates flights take-off from Dubai in a week to different cities in six continents.

Emirates entered in partnership with US Airways during 1993 and also bought a $43.6 \%$ stake in Sri Lankan Airlines by paying US\$ 70 million to Sri Lankan Government in 1998. Saleem (2010) reported that Emirates Group sold back its 44 per cent share in Sri Lankan Airlines for \$53 million (Dh194 million) through Bank of Ceylon which will keep share of Sri Lankan Airline. It had suffered a loss of almost US\$20 million on the original purchase value. In addition, it has suffered a loss of US $\$ 100$ million on the value evaluated two years ago. The partnership came to end after 12 years.

Its major competitors are Qatar Airways, Air Arabia, Etihad Airways, Kuwait Airways, Saudia and flydubai in the Middle East. It competes with Lufthansa, British Airways and Air France in international aviation market. The data of table 2(a) \& 2(b) indicates that growth parameters of Emirate Airline which are highly encouraging and company may acquire better market share in days to come. Jones (2014) reported that Emirate airline's parent company invested an unprecedented US\$6 billion in buying new aircraft, revamping products, entertainment systems, services and staff during 2013. This investment was made to fend off increasing competition from Qatar Airways and Abu Dhabi's Etihad Airways.

Emirate Airline information technology (IT) needs are met by IT division of Emirate Group named as Mercator (fully owned by Emirate Dubai National Air Travel Agency (DNATA) unit) and also having tie up with technology vendors in international market. It is important to mention, Emirate Airline had signed a deal with UK-based Vistair to provide cloud-based technical manuals for its entire fleet, including the world's biggest number of Airbus A380 superjumbos. It is further reported that Vistair will deliver added values for Emirates aircraft by supplementing Boeing and Airbus's software tools. This contact was for five years (News (2011b)). Emirate Airline will be making an 
Singh N.P.: Changing paradigm of Mercator to Accelya via Warburg Pincus - An...

investment of over US\$20 million annually towards Wi-Fi. Emirate Airline will extend free $\mathrm{Wi}-\mathrm{Fi}$ in all cabin classes. It will be its new standard of the future (Dutton-Smith (2014)). It was further reported during launch that first 10MBs data will be free and Emirates will be charging US\$1 for next $600 \mathrm{MBs}$. It was also mentioned that in future it will be free and unlimited in all types of aircraft. However, Emirates airlines had faced the constraints of speed, bandwidth availability and cost (Dutton-Smith (2014)).

Emirate Airline and ezRez Software, Inc. entered in to a new multi-year partnership. ezRez software will be the exclusive technology provider for booking of hotel rooms, car rentals and destination activities through the airline's website (www.emirates.com). With ezRez platform, Emirate Airline will have control of single global system that is deployed in 14 languages and supports payment in 42 currencies. It will also help Emirates in efficient management of its inventory (PR Newswire (2010), TBM (2010), News (2010b)). During October, 2015, Oxford University opened a new Data Science Lab in collaboration with Emirate Airline. This lab will accommodate experts from around the universities to use cutting-edge analysis of airlines data to help the airline make its services more efficient and customer-focused. The lab will develop business solutions based on big data technology and real time analytics. This lab will help Emirates to integrate large numbers of software's that are used by Emirate airline to collect, analyze, and forecast many business parameters of the company (News \& Events (2015)).

Emirate Airline is always in line with top airline of the world. New disruptive technologies such as Internet of Things (consisting of IPv6, wireless proximity-detecting technologies, such as Bluetooth low energy (BLE) beacons, radio frequency identification tags and near-field communications), Big data, data warehouse, and Cloud Computing are targeted by Airline for use in its operations. Recently, Emirates Group's IT Innovation Lab had conducted trials by embedding beacon technology into bag tags to improve both the operational and customer service aspects of baggage management at Dubai airport (Jenner (2015)). In addition, Emirates Airlines had implemented fully integrated computer/ IT systems to provide optimum fleet support to the various engineering departments of Emirate Airline.

Keeping in view, recent development, this paper presents changing paradigm of ecosystems of Mercator from its inception to its merging with Accelya. Paper attempted to provide few research propositions. These research propositions are in relation to business strategy, growth strategy, product innovation strategy, operational strategy and overall strategy for its existence. The concepts such as diversification, innovation, customer centric are the key concepts for drawing conclusion. 
Singh N.P.: Changing paradigm of Mercator to Accelya via Warburg Pincus - An...

\section{Review of Literature}

Many research scholars have studied business models, innovation models growth models, operational models etc. of various organizations. In the context of Mercator, relevant research studies are reviewed in this section. To quote, Levie and Hay (1998) concluded that large-scale empirical evidence indicated that firms do not develop according to a pre-set sequence of stages. They evolve through their own unique series of stable and unstable states related to managerial problems. They concluded that development is primarily linked to managerial problems in addition to many other contributing factors. Tavassoli and Karlsson (2015) discussed four basic types of innovation, i.e. product, process, marketing and organizational innovations. They said that there are sixteen possible combinations. This wide range of choices constitutes the innovation strategy of firms. Based on empirical study, they concluded that six innovation strategies, i.e. introducing pure product, pure process, pure marketing, pure organizational, both product and process, and finally introducing all type of innovations at the same time, account for $70 \%$ of choices. Madhushree et al (2018) discussed operational strategies in the context of one Indian IT company. According to them, operational strategies are linked to creation of new revenue streams, expertise in complex technology tools \& processes, introducing best practices, knowledge-based advice etc.

Baden-Fuller and Haefliger (2013) presented classification of business models and concluded that Business models are linked with technological innovation but its construct is essentially separable from technology. They suggested two-way relationship between business model and technology. According to them business models mediate the link between technology and firm performance and developing the right technology is a matter of a business model decision in relation to openness and user engagement. Chesbrough (2010) mentioned that companies commercialize new ideas and technologies through their business models. He further mentioned that companies have shown limited ability to innovate the business models even after making heavy investments and processes for exploring new ideas and technologies. He gave reasons for not innovating business model.

\section{Objectives and Research Methodology}

As mentioned, in the introduction, objectives of the present research paper are (i) to identify possible advantages of creation of IT division within Emirate Group for developing and implementing IT services and required strategies, (ii) to identify possible reasons for selling Mercator by Emirate group to Warburg Pincus, (iii) to identify similar management decisions with respect to creation of separate IT division by the airline industry, (iv) to identify present 
Singh N.P.: Changing paradigm of Mercator to Accelya via Warburg Pincus - An...

growth, business/ operational/ revenue management strategies specifically of Mercator, Bravo passenger solutions and Emirate Group in general, (v) to study growth model of Mercator / Aceelya before and after its acquisition by Warburg Pincus. For this purpose, the author sought support from the data for the following five research propositions.

Research Proposition 1: Mercator business strategy is based on organic growth model.

Research Proposition 2: Mercator business strategy is based on commercial opportunities and strategic partnerships which make commercial sense or It is similar to Hampel (1965) business model.

Research Proposition 3: Mercator product innovation strategy is customer (internal \& external) centric and may be termed as similar to a strategy suggested by Chesbrough (2013).

Research Proposition 4: Mercator operational strategy is customer centric and similar to strategy of efficient frontier suggested by Slack and Lewis (2008).

Research Proposition 5: Mercator overall strategy is based on diversification (both vertical \& horizontal), product \& service innovation and taking benefit of valuation in the market.

Methodology of the research paper is exploratory cum descriptive in nature. Research paper is based on qualitative and quantitative data. Data is mainly collected from Internet and web source of Emirate Group of Companies and its business partners, digital posting on web by airline industry's experts in the field of information technology applications and product development. The data is mainly qualitative in nature except the data with respect to finance and other performance parameters as given in tables 2(a) and table 2(b). The methodology consists of five steps. These are (i) search and collection of data from different sources on web, research reports, annual reports and other databases, (ii) organization / categorization of the data into concepts (iii) identifying relations between between different concepts, (iv) using occurrence of concepts to support proposition, (v) drawing meaningful conclusions based on sufficient qualitative and quantitative data.

\section{Emirate Group's Information Technology (IT) Division- Mercator}

This section presents function and objectives of Mercator along with different phases of its life not of life cycle. It is known fact that IT applications are integral part of aviation industry. All airlines across the globe are using information technology in their day to day operation as and when these 
Singh N.P.: Changing paradigm of Mercator to Accelya via Warburg Pincus - An...

information technologies are become accessible to airlines. The major usage of information technology in airline industry includes (i) electronic/ paperless tickets, (ii) transparent and clear pricing led by proactive and reactive yield management, (iii) in-flight services, (iv) commission capping and publication of net fares, (v) financial incentives for self-booking online, (vi) auctions and online promotions, (vii) powerful Customer relationship management systems, (viii) online and context-relevant advertising, (ix) airport services, (x) baggage handling etc. Emirate Airline / Emirate Group is also using information technology for the similar functions but its approach is absolutely different from other airlines of UAE and also from airlines of other countries.

Emirate Group has created Information technology division (Mercator) possibly with three main objectives. The first objective was to have workforce capable in sourcing the components or building blocks of information technology systems from different developer of technology, creates, and implement applications for Emirate airline and DNATA. The second objective was to market and implement these state-of art applications to other airlines to recover capital invested and also be in the forefront of business of airline industry technology. The third objective was to improve these IT applications based on the feedback from the users within Emirate group as well outside Emirate group. In addition, Emirate wishes to have highly skilled workforce of technocrats that will embed new technologies with existing applications to create more value for its customers. The next section presents three phases of life of Mercator.

\subsection{Phase 1: Emirate Airline and Mercator (up to 2010)}

Mercator is the IT division of Emirates Group. It was established in 1985. Its main functions were to identify, acquire, and create information technology infrastructure to meet the requirements of Emirate Airline and DNATA. With passing time, Mercator developed competencies and became a provider of airline and airport technological "solutions" to other customers of aviation industry across the globe. It had $120+$ customers in 80 countries across Middle East, Africa, Europe, America and Asia Pacific regions. The major events and organizational structure (Fig 1) of phase 1 are listed below.

(i) Developing Application by Contracting: Mercator in its initial phase was developing its applications by contacting software developer firms. Mercator and IBS Software Services, the Technopark-based travel and logistics major located in Trivandrum, India, had signed a \$4-million contract for developing a new generation cargo handling system for Mercator (Our Bureau (2002)).

(ii) Change in Platform: Tan (2006) reported that Mercator had planned to move about 180 applications to Linux within 6 to 12 months. Mercator 
Singh N.P.: Changing paradigm of Mercator to Accelya via Warburg Pincus - An...

also standardized its infrastructure on blades with sole objective to have cost advantage. The performance of the applications on Linux and blades is far better in comparison to AIX or Sun Solaris on Blade based infrastructure. Mercator is also deploying Virtual Private Networks (VPN) on Internet for better communications and will move away from proprietary communication systems, introducing service-oriented architecture as the backbone of development, and usage of mobile phones on board.

(iii) Acquisitions and Rebranding: Mercator acquired a Bangkok-based company tikAERO in 2009. It was reported that it helped Mercator to offer "fully functional, flexible and cost effective passenger service and distribution solutions to hybrid, regional, low-cost and start-up airlines worldwide". In the process Mercator also acquired 19 customers which were already using tikAERO. The architecture of tikAERO was based on Microsoft technology (Transportweekly (2010), News (2010a)). It was rebranded by Mercator as Avantik during the World Low Cost Airlines Congress in London (Mercator (2010)). It helped Mercator to serve the lucrative low-cost segment market. It employed about 400 employees in Dubai. It also had office in Bangkok. Its services consist of (i) inventory management, (ii) multi-channel reservations, (iii) yield and revenue management, (iv) departure control, (v) weight and balance, (vi) electronic ticketing, (vii) revenue accounting (viii) code-share, (ix) interlining, (x) crew management, (xi) flight control and (xii) real-time reporting to monitor business operations. It was first major acquisition by Mercator. With Avantik, Mercator had served airlines covering all shapes, sizes and business models. Hadeel (2009) reported that DNATA agreed to buy the cargo and ground handling operations at two UK airports from Britain's Go-Ahead Group. These two airports will become the potential customer of Mercator.

(iv) New Product Innovations: According to Cowell (2009), Mercator enhanced and maintained the core of its reservation and departure control technologies (Jupiter): In doing so, Mercator have invested time and money in developing its portfolio internally and taken input from majors of industry such as Farelogix (http://www.farelogix.com/) and Calidris ehf (an Iceland based revenue integrity and business intelligence application provider which was bought by Sabre Holdings during 2010). As per Mercator, Jupiter includes a consolidated suite of applications closely integrated with Mercator's airline reservation and airport control systems, MARS and MACS. Jupiter will provide business and system integration, better return on investment, process improvement and significant cost reduction. Another big thing is the next generation cargo management system which was developed in-house (Tan (2006)). 
Singh N.P.: Changing paradigm of Mercator to Accelya via Warburg Pincus - An...

(v) Partnership Agreement with HCL Infosystems MEA: HCL Infosystems MEA (Dubai based subsidiary of HCL Infosystems) signs a multi-milliondollar agreement with Mercator to ensure provision of critical applications for flydubai with an objective to lower IT expenses and ensure cost benefit for flydubai customers. It was further mentioned that HCL Infosystems brought rich experience to the IT infrastructure of flydubai. The HCL solution was optimized to save cost without compromising the required performance standards. The hi-tech infrastructure, based on the state-ofart solutions, made sure of optimum utilization of resources for all mission critical applications. The amount of the deal was not disclosed Businesswire (2010), PTI 2010)).

(vi) Acquiring Customer for its BPO Segment: Olympic Airways had outsourced its revenue accounting processes to Mercator. It was done by Olympic Airways to improve revenues, providing accurate billing and verification, reduce accounting bills, enhance productivity and eliminate the cost of employees training etc. (Wilson (2012))

(vii)Product Categorization: Mercator has categorized its offerings into five categories. The list of products of five categories and select clients are compiled in the following table 1 and organizational structure in Fig 1. In each category, Mercator is competing with different competitors.

Fig 1: Five functional units of Emirate Group IT before 2013

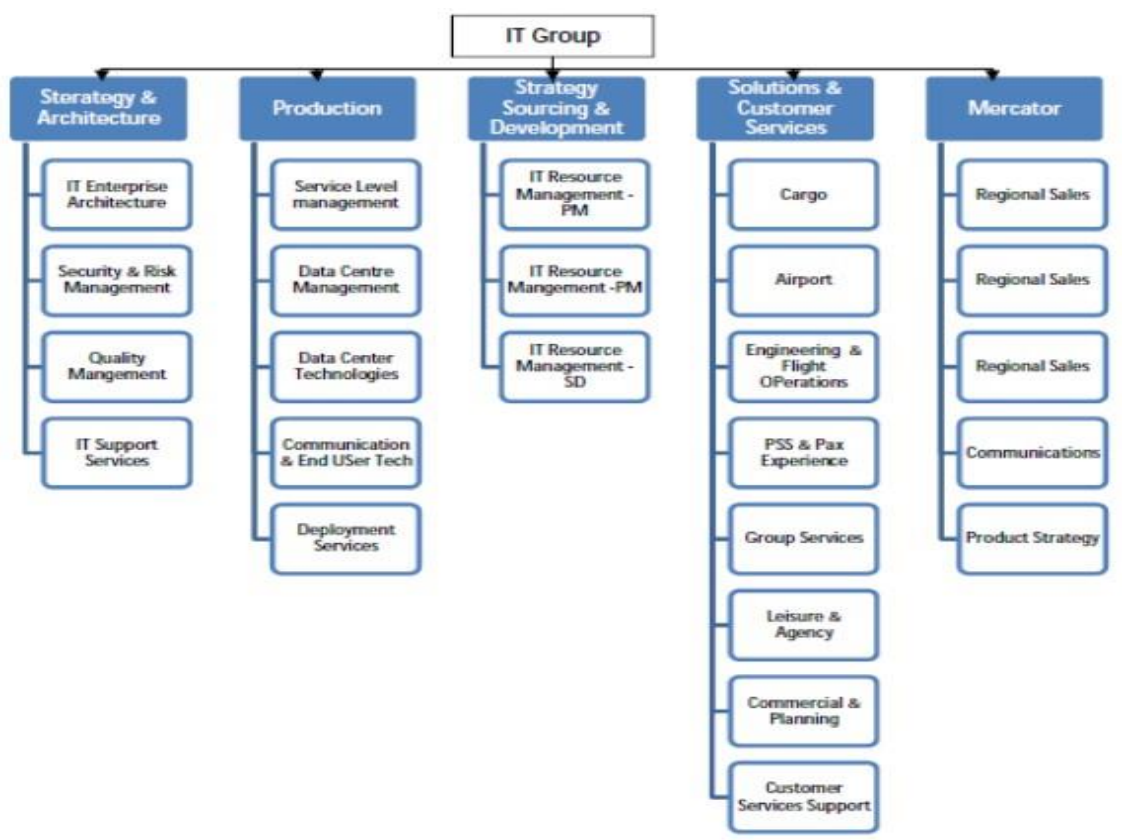


Singh N.P.: Changing paradigm of Mercator to Accelya via Warburg Pincus - An...

Table 1: Products, Product Categories, and Select Clients of Mercator

\begin{tabular}{|c|c|c|}
\hline $\begin{array}{l}\text { Product } \\
\text { Category }\end{array}$ & Products & Select Clients \\
\hline $\begin{array}{l}\text { Passenger } \\
\text { Services } \\
\text { Solutions } \\
\text { (PSS) }\end{array}$ & $\begin{array}{l}\text { Jupiter (MARS, MACS), } \\
\text { and Avantik. Jupiter is } \\
\text { integration of MARS } \\
\text { (Mercator Airline } \\
\text { Reservation System) \& } \\
\text { MACS (Mercator Airport } \\
\text { Control System). }\end{array}$ & $\begin{array}{l}\text { Kuwait Airways (Signed agreement in } 2004 \\
\text { (Southwell (2004))), Yemenia, Philippine } \\
\text { Airlines, SriLankan Airlines, Garuda Indonesia, } \\
\text { Mihin Lanka, Germania and InterSky, Maldivian } \\
\text { (Migrated in } 2013 \text { (Mercator News Room } \\
\text { (2013a), Editor (2013)). }\end{array}$ \\
\hline $\begin{array}{l}\text { Financial } \\
\text { Management } \\
\text { Solutions }\end{array}$ & RAPID/ RAPID 3.0 & $\begin{array}{l}\text { Air Mauritius, Air New Zealand, British Airways, } \\
\text { Etihad Airways, Gulf Air, Hahn Air, Oman Air, } \\
\text { Philippines Airlines (Michels (2008)), Qantas, } \\
\text { Qatar, Singapore Airlines, United Airlines, } \\
\text { Olympic Airways, and Biman Bangladesh } \\
\text { Airlines (Implemented upgraded version RAPID } \\
3.0 \text { in } 2013 \text { (Global Travel Media (2013), Staff } \\
\text { (2013), Press Release (2013b)). }\end{array}$ \\
\hline $\begin{array}{l}\text { Cargo } \\
\text { \&Logistics } \\
\text { Solutions }\end{array}$ & $\begin{array}{l}\text { SkyChain, SkyChain } \\
\text { Lite, SkyChain Handler, } \\
\text { RAPID Cargo Solutions }\end{array}$ & $\begin{array}{l}\text { Air Niugini, Avianca-Tampa, Continental } \\
\text { Airlines, Garuda Indonesia, Oman Air, Sri } \\
\text { Lankan Airlines, Swiss World Cargo, and Virgin } \\
\text { Atlantic, United Airlines (AG Reporter (2013)). } \\
\text { Air Canada (Aircargonews (2015)). }\end{array}$ \\
\hline $\begin{array}{l}\text { Safety } \\
\text { Management } \\
\text { Solutions: }\end{array}$ & Sentinel, iSaturn & $\begin{array}{l}\text { Air Canada, Air France, Air Mauritius, TAP Air } \\
\text { Portugal, Brussels Airline, Etihad Airways, } \\
\text { Royal Jordanian, Scandinavian Airlines, South } \\
\text { African Airways, and Thai Airways }\end{array}$ \\
\hline $\begin{array}{l}\text { Customer } \\
\text { Relationship } \\
\text { Management } \\
\& \quad \text { Loyalty } \\
\text { Solutions }\end{array}$ & 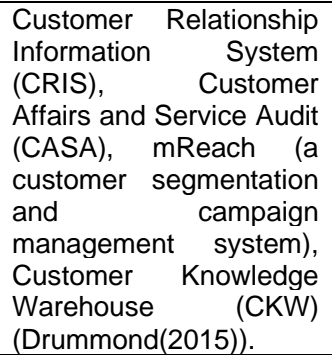 & $\begin{array}{l}\text { Aeromexico (Migrated to CRIS \& CASA to get } \\
\text { rid of legacy technology (20 applications) with } \\
\text { outdated architecture, limited features, } \\
\text { extremely expansive in terms of cost \& } \\
\text { resources in } 2010 \text { (Press Release (2012)), Air } \\
\text { Astana, Air Niugini, Cyprus Airways, Garuda } \\
\text { Indonesia, Jet Airways, Kuwait Airways, and } \\
\text { Virgin Nigeria. }\end{array}$ \\
\hline
\end{tabular}

\subsection{Phase 2: Strategic Changes and Growth of Mercator}

This section presents event between 2010 to 2014 before Mercator majority stakes was bought by Warburg Pincus. The major event includes (i) implementation of audit software's, (ii) developing CRM application, (iii) setting up development center in India, (iv) Business Agreement with Farelogix, (v) change in Vision \& Organizational Structure, and (vi) acquiring additional clients for its product and services.

(i) EDP Audit: Emirate Group (Mercator) implemented ACL software (now https://www.wegalvanize.com/) to bring changes in internal audit approach of $300+$ audit centers to get rid of manual, tedious and time- 
Singh N.P.: Changing paradigm of Mercator to Accelya via Warburg Pincus - An...

consuming tasks. It resulted in saving of manpower and more data coverage for the purpose of audit (ACL (2014)).

(ii) CRM Application: McKean (2012) reported that Emirates Airline (Mercator) created a Windows 8 based CRM application for the HP Elite Pad 900. The objective was to improve customer relations with enhanced service quality. Mercator also created its own business application known as Knowledge-driven In-flight Service (KIS), which allowed pursers to use laptops to take stock of what transpired on a flight and how to better serve passengers. KIS captures all sorts of information, anything from positive customer feedback to complaints about food to a report that a seat has a pen mark. Once the plane lands, emails go out to as many as 26 departments. The data so collected is analyzed to identify good and bad conversations of flyers, crew member during the flight.

(iii) Setting up a Development Center: Mercator and Computer Science Corporation (CSC), opened a dedicated development center (DDC) in Bangalore for its IT services. The opening of the DDC was part of a previously announced contract signed between Mercator and Covansys, a company now merged with CSC India. In partnership with CSC India, Mercator's DDC will offer travel and transportation industry, clients scalable IT services such as product development, applications development and maintenance, testing services, technology consulting and project management. DDC will work with technologies like Java, Oracle application and data warehousing, Dot Net, ERP and other specialized niche technologies. (BS Reporter (2013)). This center was opened in 2008 (CIOL Bureau (2008)).

(iv) Business Agreement with Farelogix: Mercator and Farelogix have entered into an agreement for offering Farelogix Direct Connect technology platform to Mercator's current and prospective customers. The agreement empowers Mercator to sell and implement the comprehensive repertoire of Farelogix technology, including airline direct connects in the operations of Mercator's customers including Emirate Airline. Mercator's airline customers will reap the benefits of lower cost, and highly flexible distribution technologies. In addition, Mercator will provide consulting and implementation services for Farelogix products to other airline customers (News (2011a)).

(v) Change in Vision \& Organizational Structure: Mercator was managed by group of world class IT professionals. Its IT processes and strategies are not much reported on the official website of the group but there are presentations by group top executive where its vision, mission and strategies are reported. Naef (2014) presented that Group IT made a strategic change during 2013. Before 2013, its structure was as given in figure 1. It was changed during 2013 as given in figure 2 which is very 
Singh N.P.: Changing paradigm of Mercator to Accelya via Warburg Pincus - An...

similar to an IT company structure in the business of new products or solution development as well as maintenance of new and existing products or solutions. These changes resulted due to changes in its overall strategy in relation to information technology division. The most important one was its changed Vision. Its earlier vision was "we fuel Emirate group success with information technology". It was changed to "building the future together through creative value adding IT solutions" during 2013.

(vi) Addition of Major Clients: Cargo carrier United Airlines replaced its 20 legacy systems with Mercator's SkyChain and RAPID Cargo solutions. It will save millions of dollars for United Airlines in operating cost. In addition, Mercator and United Airlines created and deployed a UC $360^{\circ}$ system that is the foundation for the future optimization of United Airlines Cargo's products, processes and technology (Mercator Newsroom (2013b)). Mercator signed an agreement with national flag carrier of the Kingdom of Thailand to manage its global cargo operations using SkyChain. The airline also engaged Mercator for its leading cargo revenue accounting solution, RAPID Cargo, along with its Unit Load Devices (ULD) management solution, NOMAD pAirport (Press Release (2012b)). Algerian based carrier, Tassilli Airlines, Thialnad startup, UAirlines, Fly Georgia, Antrak Airline of Ghana had signed agreement with Mercator for implementing Avantik PPS web based platform and taking advantage of state-of-art technology (News (2013)). Mercator is competing with Aircore, Raddix International, ACCELaero, Altea, Crane PAX, Zenith, Open Skies/New Skies, HP Agilaire/ HP Shares (Former EDS Shares), Sabre Sonic, Horizon, ARCO, Travelport Meridian, RESIBER, Astral, and AeroCRS (Strauss (2017)).

\subsection{Phase 3: Mercator with new ownership- Bravo Passenger Solutions, and Warburg Pincus:}

This section presents events and success of Mercator under Warburg Pincus. The main events covered are (i) Mercator Asia Business and Bravo Passenger Solutions, (ii) Mercator acquisition by Warburg Pincus, (iii) addition of new technologies, (iv) major acquisition by Mercator under Warburg Pincus, (v) addition of major clients, and (vi) changing segments of its solutions.

(i) Mercator Asia Business and Bravo Passenger Solutions: Avantik was founded in 1995 to provide new generation PSS for the Swissair group. In 2001, it emerged as a new business entity (Tiksystems). It was acquired by Mercator in 2010 and in 2014 acquired by Bravo (http://www.bravo.aero) passenger solutions, a Singapore based service provider to airlines. Bravo acquired $100 \%$ of the Mercator Asia business 
Singh N.P.: Changing paradigm of Mercator to Accelya via Warburg Pincus - An...

and the PSS/ Avantik product line from DNATA on May 3, 2014 (Source: https://www.workinasia.net/recruiters/bravo-passenger-solutions-co-ltd-14876.html). The objective for Bravo passenger solutions was to target low cost startup airlines with Avantik. At the same time, Bravo Passenger solutions added two significant partners in the quest for growth and to take advantage of Avantik product line. These are briefed below.

Strategic Partnership: INFINI Travel Information Inc. (HQ: Akasaka, Tokyo, Japan) invested in Bravo Passenger Solutions Pte. Ltd, a provider of reservation systems for LCC, small \& medium airlines. As per the terms of the arrangement INFINI has a seat on the Board of Directors of Bravo Passenger Solutions. This is reported on January 28, 2015 by Bravo Passenger Solutions website.

Addition of New Customer: Bravo passenger solutions added COBALT, Cyprus's new national airline as its new customer. Cyprus as hub, COBALT will connect Asia, Africa and Europe with Cyprus. This was reported on February 29, 2016 again on the website of Bravo Passenger Solutions (Newshore (2016)).

\section{(ii) Mercator Acquisition by Warburg Pincus:}

Warburg Pincus (http://www.warburgpincus.com/), a U.S. private equity firm with \$58 Billion assets acquired majority stake in Mercator in 2014 (Reuters (2014), AVB Staff (2014)). The amount of the deal and shares of majority stake were not disclosed by either Mercator or Warburg Pincus but Dnata earned Dh755 million from IT services in 2012 (Bouyamourn (2014)). It is first investment of Warburg Pincus in Middle East. Warburg Pincus was impressed with Mercator client base. Warburg Pincus would like Mercator to grow faster and develop new products in shipping and safety segment (Bouyamourn (2014), Perryman (2014)). It means Mercator international expansion is on the cards.

Strata (2014) mentioned that Technology is a key area of domain expertise and investment focus for Warburg Pincus. Warburg Pincus have been looking for a world-leading software and tech-enabled outsourcing platform to address the transport, travel and logistics sector for some time. Mercator is one of the aviation industry's leading solutions companies, benefitting from a superior product base, blue-chip customers and capable management. Warburg viewed it as an excellent platform to build a market-leading transport, travel \& logistics business of scale. Warburg looks forward to building on the expertise of the Mercator staff to accelerate the company's growth. Strata advised Warburg Pincus in acquiring stake in Mercator. It was said that deal will increase market share of Mercator and accelerate growth in terms of adding new technologies, acquiring more business \& customers. It will also end up in 
Singh N.P.: Changing paradigm of Mercator to Accelya via Warburg Pincus - An...

possible realignment of verticals. Warburg Pincus is looking for repeat of WNS BPO wherein Warburg Pincus made multiple return through four exits (Shinde (2013)). Following additions in technology, buyouts, and other events of Mercator under Warburg Pincus are proof of its diversification strategy.

\section{(iii) Addition of New Application \& Technology:}

(i) Data Warehouse: Mercator created a Customer Knowledge Warehouse (CKW), a business intelligence solution (Drummond (2015)). It will support strategic planning and forecasting for operations department. It will integrate data of several applications to derive business value out of it. (ii) Big Data Technology: Drummond (2016) reported that Airlines needs to collect and analyze data of passenger name record (PNR), origin and destination (O\&D) crossing traffic, official Airline Guide (OAG), airline tariff publishing company (ATPCO), The Air Carrier Statistics database (T-100), Airline Origin and Destination Survey (DB1B), Twitter, tour operator (B2B) sales, ancillary revenues, and weather reports, demographics of customer, behavior of the customers in addition to loyalty program data. Mercator initiated investment in applications based on Big data technology to address the needs as mentioned here (iii) Internet of Things (IoT): Hadjetian (2015) reported that Mercator is also investing in usage of Internet of Things in select segment of its airline customer's business to compete in future scenario of connected devices. Mercator had also developed industry's first open API platform for air cargo management and ground handling activities (Aircargonews (2017)).

In addition, Emirate Airlines launched an app for iPhone users on Apple app store since majority of the mobile traffic to Emirate web sites come with iPhone which operates with iOS. Earlier, Emirate Airline launched an app only for iPad users. These apps include (i) Make a booking, (ii) Check fare and book your flight, (iii) Check in and choose or change your seat on move, (iv) Mobile boarding pass, (v) Manage your booking, (vi) Change your flights, (vii) Manage your booking, (viii) Request a meal and book your chauffeur drive service, (ix) Check flight status, (x) Emirate time table, (xi) Flights, routes, connections and Timings, (xii) Services by flights such as belt number for check-in baggage and others, (xiii) List of book for aircraft type, cabin features, and in-flight entertainment before your flight, (xiv) Learn about dedicated departure lounges, (xv) Emirates skywards login to check your miles as well as present and past itineraries, (xvi) In-flight service, (xvii) Contact Emirates, (xviii) Alert when love one arrives or when your flight is due to depart (Budki (2014)).

(iv) Mercator Major Acquisitions under Warburg Pincus: 
Singh N.P.: Changing paradigm of Mercator to Accelya via Warburg Pincus - An...

Catapult International: It was acquired by Mercator in July 2015. It was a global transportation rate, quote, and contract management solutions provider. It was also known as a leading provider of technology-enabled solutions for freight forwarders, shippers, and carriers worldwide. Its product portfolio includes Catapult QMS, QMS Lite, and Spring Board (Johnson (2015)). The value of the deal was not disclosed by Mercator/ Warburg Pincus. Mercator sources mentioned that Catapult was key to its strategy for optimization of transportation process with the combination of technology, business process outsourcing, analytics, and data management (Grackin (2015)).

Seattle based Revenue Management Systems Inc.: Mercator acquires Seattle-based Revenue Management Systems, Inc. ("RMS"), the industryleading developer. More supply chain deals that happens in the industry during same time were Intrigo V/s Califta, Mercator v/s Catapult, Marlin Equity V/s IBS. Mercator/ Accelya did not disclose the terms of the transaction. (Desormeaux, H. (2016), O'Neill (2016), Grackin (2015)). It is important to mention, that over 70 world's most profitable and fastest growing airlines deploy RMS's AirRM, a cloud based state of the art, revenue management, analytics, and reporting system (News (2016)).

Anari (https://www.anari.com/): Anari is UK-based airline intel software provider. It is known as business intelligence consultancy and software development provider. Its domain includes revenue integrity and passenger profiling. Accelya with which Mercator is merged acquired Anari to become a global brand to provide tech to airlines, agencies and freight handlers (May (2017), Zalagenaite (2017)). The terms of acquisition were not disclosed.

Addition of Major Clients: Air Canada: Air Canada implemented RAPID cargo solution to "manage and optimize" its revenue accounting system for cargo operations (Aircargonews (2015)). Dnata which has minor stake in Mercator after Warburg Pincus takeover bought Brazil's RM Ground Services which had 2000 employees and serve 400 flights every day from 24 airports in Brazil. RM services will be a potential customer of Mercator products in future (Associated Press (2015)). Flydubai renewed its contract with Mercator to boost cargo operations. Flydubai will leverage the transformational offerings of the Intelligent Cargo Ecosystem (Henderson (2017)).

Changes in Solution Segmentation: Mercator divided its solutions into four verticals in place of five as mentioned in section 3.1. These are (i) airline revenue accounting, (ii) airline cargo management, (iii) airline customer experience, and (iv) airline passenger services. Later on the solution segments were changed as shown in fig 2 . The new structure has five segments / verticals in place of earlier four. 
Singh N.P.: Changing paradigm of Mercator to Accelya via Warburg Pincus - An...

Fig 2: Functional units of Emirate Group IT after 2013

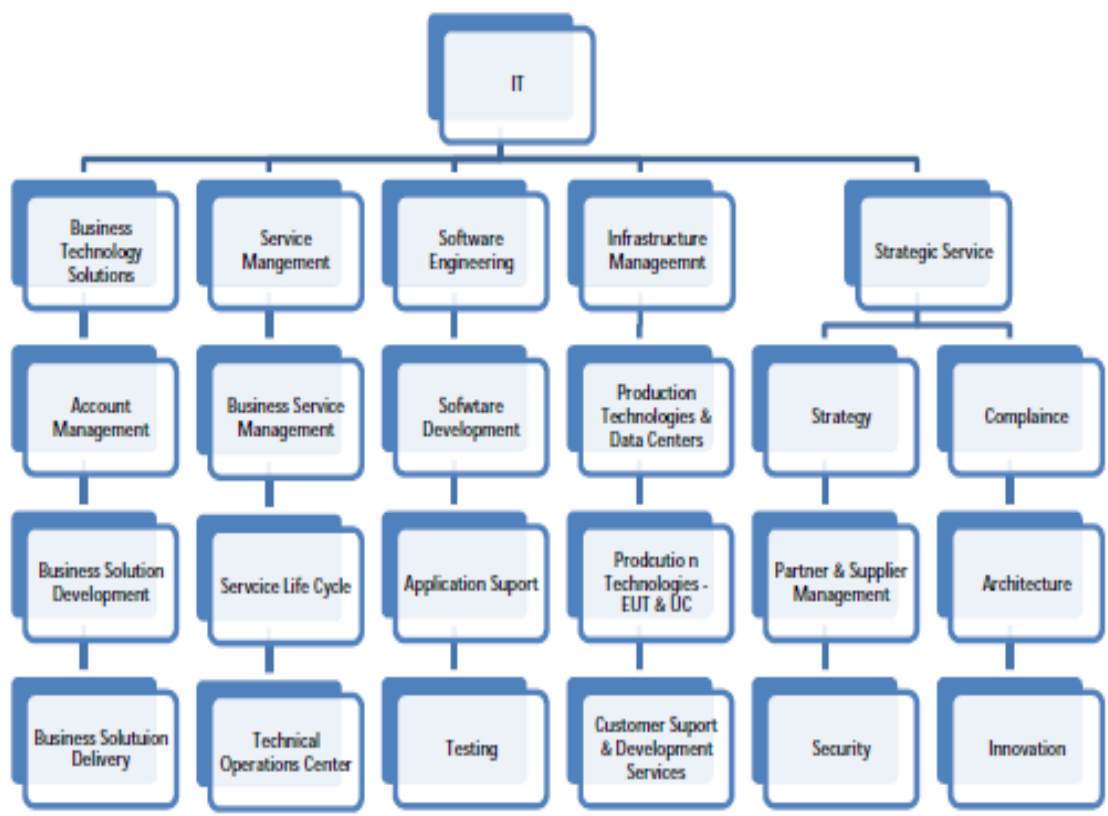

\subsection{Phase 4: Mercator, Accelya and Warburg Pincus}

Accelya (https://w3.accelya.com/): It is a Barcelona-based airlines services company. Accelya Lake Solutions Ltd, one of the entity of Accelya group is listed on Bombay Stock Exchange in India (Jha (2017)). Its customer list includes airlines like American Airlines, British Airways, Air Canada, Avianca, Easyjet, Air Asia, FINNAIR, Jet Blue, Garuda (Indonesia), Qantas, Swiss World Cargo, Thai Cargo, Westjet, Vueling, Raynair, Sri Lankan Air etc. It is merging with Mercator. As per the term of merger, the combined companies will retain their separate brands (O'Neill (2017)). The combined company will provide accounting, audit, and other financial services to make it strong competitor to Amadeus, Sabre, Travelport, and Travelsky in terms of services if not in dollar value. Mercator is still small in comparison to Amadeus, a billion-dollar company. Accelya financial and commercial solutions + Mercator's product-enabled solutions to the travel and transportation industry had created a global technology-enabled solutions provider to airlines, travel agents and transport companies. These are complementary products portfolios and will enhance offerings of combined entity. The combined entity will be at the forefront of automation, helping customers in managing their financial processes more efficiently, minimizing revenue leakages, reducing 
Singh N.P.: Changing paradigm of Mercator to Accelya via Warburg Pincus - An...

operational costs and optimizing management of their indirect distribution channel. It is further reported that combined entity will have more than 400 clients including 250 airlines as its customers (Press Release (2017), PR Newswire (2017)). Combined entity will be named as Accelya and it will be the beginning of rebranding of products as Accelya brand in the long run (STAT Times (2017)). The combined entity will have pro forma revenue in excess of \$200 million (Jha (2017)).

\section{Analysis}

This section presents additional data and analysis of data/ facts presented in earlier sections with respect to Mercator growth model, implementation models, business model, advantage of having separate IT division, reasons for selling majority stake to Warburg Pincus, etc. by linking to different research propositions.

\subsection{Growth Model/ Strategy:}

Research Proposition 1: Mercator growth strategy is based on organic growth model.

Emirate group invested its resources in creating information technology/ system's products since its inception. Patrick Naef made a statement that "Most compelling fact about Mercator is the fact that we build all our products in house, rather than trying to recreate a patchwork of brought systems" (Attwood (2009)). This is partly true. Mercator bought companies and marketed these products with some integration related changes to needs of its customers as mentioned in earlier sections. Therefore, its growth model / strategy can be termed as both organic (phase-1) and inorganic (Phase 2, Phase 3, and Phase 4). Inorganic business model is evident from the list of its partnerships and acquisitions which includes (i) dedicated computer center (DDC) with computer science corporation in Bangalore, India (BS Reporter (2013)), (ii) tikAERO, Catapult International, (iii) Seattle-based Revenue Management Systems, Inc. etc. ("RMS")). Organic growth is evident form Mercator's abilities to integrate acquired technologies, processes, and adding value to the existing solutions. Mercator created these abilities in time. The data presented in this section and in earlier sections of research paper partly support the proposition 1. Growth model of Mercator before and after its acquisition by Warburg Pincus remains hybrid (organic + inorganic). Mercator under Warburg Pincus acquired two more companies during 2015 and 2016 which did not support the proposition. The basic parameters of Emirate Group performance given in Table 2(a) and Table 2(b) support the proposition for the group as a whole but not IT division. IT group being part of Emirate group will be impacted by the strategy of group. 
Singh N.P.: Changing paradigm of Mercator to Accelya via Warburg Pincus - An...

Table 2 (a): Emirates Fact Sheet

\begin{tabular}{|c|c|c|c|c|c|c|c|}
\hline Parameters & \multicolumn{7}{|c|}{ Years } \\
\hline $\begin{array}{c}\text { Turnover (AED } \\
\text { Million) }\end{array}$ & 2005 & 2006 & 2007 & 2008 & 2009 & 2010 & 2011 \\
\hline $\begin{array}{c}\text { Net Profit (AED } \\
\text { Million) }\end{array}$ & 2,619 & 2,652 & 3,339 & 4,451 & 2,278 & 3,565 & 5,443 \\
\hline $\begin{array}{c}\text { Passenger (Millions) } \\
\text { No of Aircraft }\end{array}$ & 12,529 & 14,498 & 17,544 & 21,229 & 22,731 & 27,454 & 31,422 \\
\hline $\begin{array}{c}\text { No of Destinations } \\
\text { No of Employees }\end{array}$ & 15,858 & 17,296 & 20,273 & 23,650 & 35,812 & 36,652 & 38,797 \\
\hline $\begin{array}{c}\text { Passenger Seat } \\
\text { Factor (\%) }\end{array}$ & 74.6 & 75.9 & 76.2 & 79.8 & 75.8 & 78.1 & 80.0 \\
\hline $\begin{array}{c}\text { Available Seat KMs } \\
\text { (ASKM Million) }\end{array}$ & 68,930 & 82,008 & 102,337 & 118,290 & 134,180 & 161,756 & 182,757 \\
\hline $\begin{array}{c}\text { Overall capacity } \\
\text { (ATKM Million) }\end{array}$ & 13,292 & 15,803 & 19,414 & 22,078 & 24,397 & 28,526 & 32,057 \\
\hline $\begin{array}{c}\text { Cargo Carried (000 } \\
\text { tones) }\end{array}$ & 838 & 1,019 & 1,156 & 1,282 & 1,408 & 1,580 & 1,767 \\
\hline $\begin{array}{c}\text { Total Assets (AED } \\
\text { Million) }\end{array}$ & 23,718 & 31,393 & 37,958 & 46,511 & 47,449 & 55,547 & 65,090 \\
\hline $\begin{array}{c}\text { Cash Assets (AED } \\
\text { Million) }\end{array}$ & 7,328 & 9,199 & 8,070 & 2,714 & 7,368 & 10,511 & 13,973 \\
\hline $\begin{array}{c}\text { Return on } \\
\text { Shareholder's funds } \\
\text { (\%) }\end{array}$ & $\mathrm{n} / \mathrm{a}$ & $\mathrm{n} / \mathrm{a}$ & $\mathrm{n} / \mathrm{a}$ & $\mathrm{n} / \mathrm{a}$ & 4.4 & 21.6 & 28.3 \\
\hline
\end{tabular}

Source: Annual Reports of the company

Table 2 (b): Emirates Fact Sheet

\begin{tabular}{|c|c|c|c|c|c|c|c|}
\hline Parameters & Years & & & & & & \\
\hline & 2012 & 2013 & 2014 & 2015 & 2016 & 2017 & 2018 \\
\hline $\begin{array}{l}\text { Turnover (AED } \\
\text { Million) }\end{array}$ & 62,287 & 73,113 & 82,636 & 88,819 & 85,044 & 85,083 & 92,322 \\
\hline $\begin{array}{l}\text { Net Profit (AED } \\
\text { Million) }\end{array}$ & 1,813 & 2,839 & 3,254 & 5,893 & & & \\
\hline Passenger (Millions) & 33,981 & 39,391 & 44,537 & 48,139 & 51,853 & 56,076 & 58,485 \\
\hline No of Aircraft & 169 & 197 & 217 & 231 & 251 & 259 & 268 \\
\hline No of Destinations & 132 & 133 & 142 & 144 & 153 & 156 & 157 \\
\hline No of Employees & 42,422 & 47,678 & 52,516 & 56,725 & 61,205 & 64,768 & 62,356 \\
\hline $\begin{array}{c}\text { Passenger Seat } \\
\text { Factor (\%) }\end{array}$ & 80.0 & 79.7 & 79.4 & 79.6 & 76.5 & 75.1 & 77.5 \\
\hline $\begin{array}{c}\text { Available Seat KMs } \\
\text { (ASKM Million) }\end{array}$ & 200,687 & 236,645 & 271,133 & 295,740 & 333,726 & 368,102 & 377,060 \\
\hline $\begin{array}{l}\text { Overall capacity } \\
\text { (ATKM Million) }\end{array}$ & 35,467 & 40,934 & 46,820 & 50,844 & 56,383 & 60,461 & 61,425 \\
\hline $\begin{array}{l}\text { Cargo Carried (000 } \\
\text { tones) }\end{array}$ & 1,796 & 2,086 & 2,250 & 2,377 & 2,509 & 2,577 & 2,623 \\
\hline $\begin{array}{l}\text { Total Assets (AED } \\
\text { Million) }\end{array}$ & 77,086 & 94,803 & 101,604 & 111,362 & 119.179 & 121,558 & 127,587 \\
\hline $\begin{array}{l}\text { Cash Assets (AED } \\
\text { Million) }\end{array}$ & 15,587 & 24,572 & 16,561 & 16,885 & 19.988 & 15,668 & 20,420 \\
\hline $\begin{array}{c}\text { Return on } \\
\text { Shareholder's funds } \\
(\%)\end{array}$ & 7.2 & 10.4 & 13.6 & 17.2 & 23.8 & 3.8 & 7.9 \\
\hline
\end{tabular}

Source: Annual Reports of the Company 
Singh N.P.: Changing paradigm of Mercator to Accelya via Warburg Pincus - An...

\subsection{Business Model / Strategy:}

Research Proposition 2: Mercator business strategy is based on commercial opportunities and strategic partnerships which makes commercial sense (means monetization) thereby it is similar to Hampel (1965) business model.

Emirate group business model can be characterized as unique for airline industry. It has invested in creating IT application and solutions. It has created a brand (Mercator) for its applications and solutions. It is using these applications internally as an airline itself. It is marketing these applications to competitors to recover the capital invested. It has created systems so that migration to Mercator systems helps companies to reduce the cost of operation and help in getting rid of large number of legacy systems (AG Reporter (2013)).

For instance, Mercator has reduced the cost of operation to United Airlines by replacing its legacy systems. In addition, Mercator keeps on acquiring companies, new technologies with better features and less cost, improving business processes, making agreement in all geographical areas based on commercial sense and opportunity and reducing the stake in the brand/ unit if valuation by investors is above the benchmark value fixed by the emirate group. This model is similar to business model of Hampel (1965) which has two dimensions, i.e., value creation and value capture. Value creation is about customer identification and value capture is delivery and monetization of value. As evident from data presented in the paper, Mercator first created the value and then monetized it and delivered to customers. The research paper had sufficient data to support this proposition to great extent.

\subsection{Innovation Models:}

Research Proposition 3: Mercator product innovation strategy is customer (internal \& external) centric and may be termed as similar to a strategy suggested by Chesbrough (2013).

Mercator upgraded the features of its products as per the future need of the customers. Mercator added new features for six custom authorities - US, UK, Nigeria, Korea, Mexico and Canada. Out of these six customers, UK and US are directly interfaced with SkyChain. Additional key features include Quick Pack functionality for small packages, customization for the Cargo Portal Service (CPS), interaction with United's Bag Tag System (BDS), and inclusion of Transportation Security Administration (TSA) requirements (AG Reporter (2013)). It was reported as an example that United Airlines replaced its cargo logistics and revenue accounting systems to Mercator's SkyChain and RAPID Cargo solutions. The migration helped United Airline in getting rid of 20 legacy systems and saving millions of dollars in operational costs. United Airlines 
Singh N.P.: Changing paradigm of Mercator to Accelya via Warburg Pincus - An...

expects to have over two million bookings and 1.5 million air waybills every year on its more than 6,000 daily flights with over 700 aircraft that fly to 10 major hubs and over 400 airports worldwide (AG Reporter (2013)). Accelya/ Mercator product strategy can be compared with views of Chesbrough (2010). Mercator / Accelya clients work in an environment of fierce competition and not willing to innovate their business models. This is a similar scenario as researched by Chesbrough (2013). Mercator/ Accelya develops product to help airlines reduce cost without much innovation at business model level. However, in the recent years some airlines have been accepting challenges on innovation (Drummond (2019)). Therefore, it is concluded that research proposition had support in the literature as well as data presented in this research paper.

\subsection{Operational Strategy/Model}

Research Proposition 4: Mercator operational strategy is customer centric and similar to strategy of efficient frontier suggested by Slack and Lewis (2008).

All companies claim to have their operational strategy as customer centric. Mercator or Accelya is known to help airlines including Emirates Airline and other customers (individual \& companies) for tracking baggage \& end-to-end view of cargo movement across supply chain, determining optimal carriers for routes and provide fast \& accurate rates, simplification of rates and quote management, increasing productivity \& efficiency of operations with customer satisfaction, managing customer loyalty programs, etc. In addition, Mercator or Accelya had revenue streams by acquiring companies and having partnerships. Based on this data and data presented in other sections, Mercator or Accelya operational strategy may be termed as the strategy of efficient frontier suggested by Slack and Lewis (2008). This research proposition is true to a certain extent in case of Mercator / Accelay.

\subsection{Overall Strategy for Existence}

Research Proposition 5: Mercator overall strategy is based on diversification (both vertical \& horizontal), product \& service innovation and taking benefit of valuation in the market.

Mercator is itself a diversification by Emirates group. Having existed with Emirates group, Mercator continues to diversified by adding more and more products to its basket of applications, improving existing application with internal innovation and if internal stagnation is impeding the objective then working in partnership or even acquiring the companies which not only bring products and customers but new and sharp skills in the given domain of 
Singh N.P.: Changing paradigm of Mercator to Accelya via Warburg Pincus - An...

acquired company. Its history from ezRez software to being part of Accelya is an example of its diversification. In addition, the following two events also support its diversification strategy and market valuation strategy.

Mercator as a Separate IT division within Emirate Group: As a separate unit in the form IT company, it can attract best information technology professionals to work with in creating best quality IT solutions. For an airline it is difficult to retain talented IT professionals. With a trained and competent workforce Emirate Group could innovate and create a brand "Mercator" for its applications and solutions. It has attracted large number of competitor airlines to implement its quality products/solutions. It could also attract IT companies to work with Emirate Group-IT. It can attract investment which will help in diversification of product and services.

Selling Majority Stakes to Warburg Pincus: One of the most important possible reasons for Mercator to sell off majority stake is high valuation of Mercator by Warburg Pincus. Financial performance of the group as shown in table 1 also indicates that group might have got its value for money it has invested in the last 20 years. Second possible reason could be to increase its reach in other markets across the globe specifically in North America and also in South America. Third reason could be to reduce risk. Airline industry is a high risk industry in terms of operations of aircraft which are using information technology in a big way. Mercator needs to be bigger to venture in high tech domain. It may not be possible for Mercator with Emirate Group-IT. With Warburg Pincus it is possible. Risk is also mitigated. It is now responsibility of Warburg Pincus not of Emirate Group-IT. Fourth possible reason could be thinking within Emirate Group to concentrate on core business rather than application of information technology. Fifth reason could be internal innovation stagnation in terms of developing application with new technologies such as IoT, Big Data etc. The last reason could be lessons learned from the deal with Sri Lankan Airlines. This data is an ample proof of its diversification strategy as well taking advantage of valuation in the market.

To sum up not many cases like Mercator are reported in the literature from airline industry. However, there are IT companies such as SITA which are promoted by many airlines together but not by a single airline. In telecom sector there are many groups of companies who have invested in tower companies and Mobile Virtual Nnetork Operator companies. Tower Companies are created by Mobile Network Operators for their own use and at the same time marketing services of these companies to other competitor companies. These all are ultimately having similar functions (Singh (2010)). Emirate Group still has minority stake in Mercator. Emirate Airline and DNATA is still using systems, solutions and applications of Mercator. The existing business model between Mercator and Emirate Airline is not reported either by Emirate Airline or DNATA or Warburg Pincus. Bravo Passenger Solutions 
Singh N.P.: Changing paradigm of Mercator to Accelya via Warburg Pincus - An...

have bought $100 \%$ stake in Mercator South Asia. Emirate group may not be using systems or solutions of Mercator South Asia since these solutions were for low cost startup airlines. Emirate Airline is not in this category (Singh (2018)). Accelya and Mercator will join to create a global technology-enabled solutions provider to airlines, travel agents and freight forwarders. Their complementary offerings will include revenue accounting, revenue management and revenue assurance, cargo management, payment solutions, data analytics, cost management and commercial solutions (Burns (2017)). The combined entity is called now Accelya (https://w3.accelya.com/).

\section{Concluding Remark}

To conclude, in view of very basic nature of airline industry, it was a right decision of Emirate to sell off majority stake of Mercator and $100 \%$ stake of Mercator South Asia. Emirate Airline and DNATA will now concentrate on core business of flying with passenger and cargo. In the era of specialties; it is not possible for an airline company to cope with changes happening in the information technology. For instance, Nokia was a very successful manufacturer of mobile phone handsets but could not become a best operating system developer (Singh (2014)). In the process of developing a best operating system it lost hardware business also. For Emirate Airline or Group, it is most important to be a best airline in the days to come based on its past achievements rather than becoming a best IT company. Further its decision to retain minority stake of Mercator will help Emirate group to know recent happening in airline's information technology applications. "Mobile technology and open API platforms will revolutionize the industry, allowing carriers to get a real-time digital view of the entire air cargo supply chain. The technology can really transform the industry, providing much greater visibility, versatility, and above all, the ability to simplify complex and challenging processes." (Aircargonews (2017)). This may be possible with Accelya + Mercator + Warburg Pincus but not solely by Mercator under Emirate Group.

\section{References}

-ACL. (2014). Emirates airline- Emirates airline gains a more comprehensive view of its business operations. Retrieved from http://www.acl.com/pdfs/ Success_Story UtlitiesTrans_Emirates.pdf (moved to scribd.com).

-AG Reporter. (2013). Mercator is united airlines new cargo partner. Retrieved from https: //arabiangazette. com/dubai-mercator-united-airlines-cargolaunch-largest-cargo-solutions-20130827/.. 
Singh N.P.: Changing paradigm of Mercator to Accelya via Warburg Pincus - An...

-Aircargonews. (2015). Air Canada plugs into Mercator's RAPID Cargo. Retrieved from http://www.aircargonews.net/news/singleview/news/aircanada-plugs-into-mercators-rapid-cargo.html.

-Aircargonews. (2017). WCS17: Mercator promises revolution in airfreight systems. Retrieved from http://www.aircargonews.net/news/policy/government/singleview/news/wcs17-mercator-promises-revolution-in-airfreightsystems.html.

Dubai's dnata buys stake in brazil airport services firm. (2015). Associated Press. Retrieved from http://www.dailymail.co.uk/wires/ap/article3333281/dubais-dnata-buys-stake-brazil-airport-services-firm-rm.html.

Attwood, E. (2009). Mercator maps out of future. Retrieved from https: //www. logisticsmiddleeast. com/article-1927-mercator-maps-out-thefuture?utm_source=Jarvis\&utm_medium=logisticsmiddleeast. com\&utm_campaign=recommended.

-AVB Staff. (2014). US firm buys Emirates Mercator. Retrieved from http://www.arabianindustry.com/aviation/news/2014/apr/9/us-firm-buysemirates-mercator-4658277/.

Bouyamourn, A. (2014). Warburg Pincus buys Dubai-based aviation IT firm Mercator from Dnata. Retrieved from http://www.thenational.ae/business/industry-insights/aviation/warburgpincus-buysdubai-based-aviation-it-firm-mercator-from-dnata..

-BS Reporter. (2013). Mercator set up center in B'lore. Retrieved from http://www.business-standard.com/article/technology/mercator-sets-upcentre-in-b-lore-108040501038_1.html.

Budki, S. (2014). Emirates Airlines launches app for iPhone; Android version in making. Retrieved from http://www.themobileindian.com/news/15575_Emirates-Airlineslaunches-app-foriPhone-Android-version-in-making.

Burns, J. (2017). Accelya and Mercator join forces. Retrieved from http://www.aircargoweek.com/accelya-mercator-joins-forces/.

-Businesswire. (2010). HCL Info systems MEA and Mercator to manage Flydubai IT infrastructure. Retrieved from http://businesswireindia.com/news/news-details/hcl-infosystems-meamercator-manage-flydubai-it-infrastructure/24647.

-CIOL Bureau. (2008). Mercator, CSC set up center in Bangalore. Retrieved from https://www.ciol.com/mercator-csc-set-center-bangalore/.

Cowell, S. (2009). Mercator speeds up the future of trave. Retrieved from http://www.arabiansupplychain.com/article-3148-mercatorspeeds-upthe-future-of-travel/.

Desormeaux, H. (2016). Mercator acquires revenue management product developer. Retrieved from https://www.americanshipper.com/news/ ?autonumber=63594\&source $=r$ edirected-from-old-site-link. 
Singh N.P.: Changing paradigm of Mercator to Accelya via Warburg Pincus - An...

Drummond, M. (2015). Big Data Makes CRM more important than ever for Airlines. Retrieved from https://w3.accelya.com/blog/big-data-makescrm-more-important-than-ever-for-airlines.

Drummond, M. (2016). Driving airline profitability with big data. Retrieved from http://www.mercator.com/blog/driving-airline-profitability-withbig-data.

Dutton-Smith, J. (2014). Emirate announces new aircraft, free wi-fi, new route \& technology first. Retrieved from http://www.flightcentre.com.au/travelnews/travel-news/emirates-announce-newaircraft-free-wi-fi-new-routetechnology-first/.

Editor, (2013). Maldivian migrates to Mercator's passenger services solutions. Retrieved from https://www.eturbonews.com/70312/maldivian-migratesmercator-s-passenger-services-solutions/.

-Global Travel Media. (2013). Mercator new and improved RAPID 3. O to support Biman Bangladesh Airlines growth. Retrieved from http://www.eglobaltravelmedia.com.au/mercators-new-and-improvedrapid-3-0-to-support-biman-bangladesh-airlines-growth/.

Grackin, A. (2015). More Supply Chain Deals: Intrigo-Califta, MercatorCatapult, Marlin-IBS. Retrieved from http://www.clresearch.com/research/detail.cfm?guid=A2C97662-304879ED-9976-ABCF7E08C552.

Hadeel, (. (2009). DNATA buys two UK airport firms. Retrieved from https://www.thenational.ae/business/dnata-buys-two-uk-airport-firms1.546740 .

Hadjetian, L. (2015). Internet of Things and the Future of Air Trave. etrieved from https://w3.accelya.com/blog/internet-of-things-and-the-future-of-airtravel.

Henderson, J. (2017). Flydubai renews content with Mercator to boost cargo operations. Retrieved from http://www.supplychaindigital.com/distribution/flydubai-renews-contractmercator-boost-cargo-operations.

Jenner, G. (2015). ANALYSIS: How airlines are tapping into the Internet of Things. Retrieved from https://www.flightglobal.com/news/articles/analysis-how-airlines-aretapping-intothe-internet-of-414073/.

Jha, D. (2017). Warburg Pincus acquires airline services group Accelya; Dubai-based Mercator and Accelya to merge. Retrieved from https://www.ibtimes.co.in/warburg-pincus-acquires-airline-servicesgroup-accelya-dubai-based-mercator-accelya-merge-714885.

Johnson, E. (2015). Mercator acquires Catapult International. Retrieved from http://www.americanshipper.com/Main/News/Mercator_acquires_Catapu It_International_60659.aspx.

Jones, R. (2014). Emirates Airline Betting on Record Investment. Retrieved from 
Singh N.P.: Changing paradigm of Mercator to Accelya via Warburg Pincus - An...

http://www.wsj.com/articles/SB100014240527023046553045795491414 92534948.

Levie, J., \& Hay, M. (1998). Progress or just proliferation? A historical review of stagesmodels of early corporate growth. In London Business School Working Paper. FEM wp 98.5..

Madhushree, R.R., Kumar, A., \& Aithal, P.S. (2018). Business strategy of top Indian IT company: Mindtree. International Journal of Case Studies in Business, IT and Education (IJCSBE), 2(1), 22-36. DOI:http://dx.doi.org/10.5281/zeodo.1249871.

May, K. (2017). Accelya acquires business intelligence tech service Anari. Retrieved on from https://www.tnooz.com/article/accelya-acquiresbusiness-intelligence-brand-anari/.

Mckean, A. (2012). Emirates Airlines creates a Windows 8 CRM application for the sky. Retrieved from http://searchcrm.techtarget.com/feature/Emirates-Airlines-creates-aWindows-8-CRM-application-for-the-sky.

-Mercator. (2010). Mercator unveils Avantik to world's low cost carriers. Retrieved from https://www.internationalairportreview.com/news/3369/mercator-unveilsavantik-to-worlds-low-cost-carriers/.

-Mercator Newsroom. (2013). Mercator and United Airlines Cargo Launch One of the Largest Cargo IT Solutions. Retrieved from https://w3.accelya.com/mercator-and-united-airlines-cargo-launch-oneof-the-largest-cargo-it-solutions..

Michels, J. (2008). Philippine Airlines installs rapid revenue accounting system. Retrieved from https://aviationweek.com/awin/philippine-airlinesinstalls-rapid-revenue-accounting-system.

Naef, P. (2014). World class for a world class business - IT as a driver for transformation. In 9th Sogeti Executive Summit, 2014. Retrived from http://www.slideshare.net/VINTlabs/design2disrupt-patrick-naefemirates-a-30-yearold-start-up.

Oxford-Emirates Data Science Lab will streamline air travel. (2015). News \& Events ; Retrieved from http://www.ox.ac.uk/news/2015-10-29-oxfordemirates-data-science-lab-will-streamline-airtravel.

Mercator acquires next generation tikAERO to serve hybrid, regional and low cost airlines. (2010). News; Retrieved from http://www.emirates.com/fr/english/about/news/news_detail.aspx?article $=577452$.

Emirates Airline and ezRez Software Announce Global Technology Partnership. (2010). News; Retrieved from https://www.albawaba.com/news/emirates-airline-and-ezrez-softwareannounce-global-technology-partnership. 
Singh N.P.: Changing paradigm of Mercator to Accelya via Warburg Pincus - An...

Mercator and Farelogix to Amplify Airline Direct Connect Reach Worldwide. (2011). News; Retrieved from https://w3.accelya.com/mercator-andfarelogix-to-amplify-airline-direct-connect-reach-worldwide.

Emirate chooses UK's Vistair for DocuNet and CrewNet services. (2011). News; Retrieved http://web.vistair.com/news/7/emirates-chooses-uksvistair-for-cloud-based-e-man/.

Mercator acquires revenue management systems, April 04. (2016). News; Retrieved on April 11, 2019 from http://ww1.revenuemanagement.com/news/mercator-acquires-rms.

-Newshore. (2016). Newshore has been selected by COBALT, Cyprus's new national carrier to implement its internet booking engine. Retrieved from https://www.newshore.es/home/news/newshore-has-been-selected-bycobalt-to-implement-its-internet-booking-engine/.

o'Neill S., (2016). Warburg Pincus- backed Mercator acquires Revenue Management Systems. Retrieved from https: //www. tnooz. com/article/mercator-warburg-pincus-RMS/..

o'Neill S., (2017). Airline services leaders Accelya and Mercator announce merger. Retrieved from https: //skift. com/2017/02/06/airline-servicesleaders-accelya-and-mercator-announce-merger/.

-Our Bureau. (2002). IBS cargo handling software for Mercator. Retrieved from

http://www.thehindubusinessline.com/2002/09/28/stories/200209280163 0600.htm.

Perryman, E. (2014). Warburg Pincus acquire majority stake in Mercator from dnata. Retrieved from https://www.privateequitywire.co.uk/2014/04/09/200467/warburg-pincusacquire-majority-stake-mercator-dnata.

-PR Newswire. (2010). Emirate Airline ezRez software announce global technology partnership. Retrieved from https://www.prnewswire.com/news-releases/emirates-airline-and-ezrezsoftware-announce-global-technology-partnership-104767969.html.

-PR Newswire. (2017). Combination of Accelya and Mercator completes, creating a leading global solutions provider to the travel industry. Retrieved from http://www.prnewswire.co.in/news-releases/combinationof-accelya-and-mercator-completes-creating-a-leading-global-solutionsprovider-to-the-travel-industry-300425827.html.

Mercator Delivers Loyalty Solution to Club Premier. (2012). Press Release; Retrieved from https://w3.accelya.com/mercator-delivers-loyaltysolution-to-club-premier.

Mercator's technologies selected to support THAl cargo growth aspirations. (2012). Press Release; Retrieved from https://w3.accelya.com/mercators-technologies-selected-to-support-thaicargo-growth-aspirations. 
Singh N.P.: Changing paradigm of Mercator to Accelya via Warburg Pincus - An...

ombination of Accelya and Mercator Completes, Creating a Leading Global Solutions Provider to the Travel Industry. (2017). Press Release; Retrieved from https://www.realwire.com/releases/Combination-ofAccelya-and-Mercator-Completes.

-PTI. (2010). HCL Infosystems bags contract from Emirate Group. Retrieved from https://economictimes.indiatimes.com/tech/ites/hcl-infosystemsbags-contract-from-emirates-group/articleshow/6902144.cms?from=mdr.

Warburg Pincus buys majority stake in Emirates' aviation tech firm. (2014). Reuters.

Retrieved

from http://www.reuters.com/article/emiratesmercatoridUSL6N0N00SC20140408.

Saleem, N. (2010). Emirates sells Sri Lankan stake. Retrieved from http://gulfnews.com/business/aviation/emirates-sells-srilankan-stake1.652115.

Shinde, S. (2013). Warburg Pincus signals formal exit from WNS. Retrieved from https://www.business-standard.com/article/companies/warburgpincus-signals-formal-exit-from-wns-113011800210_1.html.

Singh, N.P. (2010). Competitive Landscape of Mobile Telecommunications Tower Companies in India. International Journal of Interdisciplinary Telecommunications and Networking, 2(1), 49-81. doi:10.4018/jitn.2010010104

Singh, N.P. (2014). Microsoft Acquired Nokia in Unipolar Operating System Market. Independent Journal of Management \& Production, 5(3), doi:10.14807/ijmp.v5i3.166

Singh, N.P. (2018). Information Technology at Emirate Group - Case of Mercator. In Proceedings of 5th International GSOM Conference, 2018. Russian Federation: Saint Petersburg University. pp 405-407. October 4-6.

Southwell, M. (2004). Kuwait Airways opts for Mercator. Retrieved from http://www.arabianbusiness.com/kuwait-airways-opts-formercator136029.html.

-Staff. (2000). Olympic airways uses emirates Mercator systems. Retrieved from http://aviationweek.com/awin/olympic-airways-uses-emiratesmercator-system.

-STAT Times. (2017). Accelya is the new name for the combined Accelya \& Mercator business. Retrieved from http://www.stattimes.com/accelya-isthe-new-name-for-the-combined-accelya-and-mercator-business-supplychain.

-Strata. (2014). Strata advises Warburg Pincus on the acquisition of a majority stake in Mercator from Emirates group. Retrieved from http://www.stratapartners.com/strata-advises-warburg-pincus-on-the-acquisition-of-amajority-stake-in-mercator-from-emirates-group/. 
Singh N.P.: Changing paradigm of Mercator to Accelya via Warburg Pincus - An...

Strauss, M. (2017). Travel technology for dummies: What is a passenger service system. Retrieved from http://www.travel-industryblog.com/travel-technology/pss/.

Tan, A. (2006). Emirate soars high on tech. Retrieved from http://www.zdnet.com/article/emirates-soars-high-on-tech/.

Tavassoli, S., \& Karlsson, C. (2015). Firms' Innovation Strategies Analyzed and Explained. CESIS Electronic Working Paper Series, Paper No. 396.

-TBM. (2010). Emirates Airline and ezRez Software Announce Global Technology Partnership. Retrieved from http://www.travelbizmonitor.com/Aviation/emirates-airline-and-ezrezsoftware-announce-global-technology-partnership-11736.

-Transportweekly. (2010). Mercator acquires next generation tikAERO to serve hybrid, regional and low-cost airlines. Retrieved from http://www.transportweekly.com/pages/en/news/articles/72986/.

Wilson, G. (2012). Olympic airways hands over accounting processes to Mercator. Retrieved from https: //www. arabianbusiness. com/olympicairways-hands-over-accounting-processes-mercator-212221. html.

Zalagenaite, Z. (2017). Anari acquired by Accelya and Warburg Pincus. Retrieved from https: //aerotime. aero/en/aviation-finance/finance/18916anari-acquired-by-accelya-and-warburg-pincus. 